\title{
Structural development of the Tertiary fold-and-thrust belt in east Oscar II Land, Spitsbergen
}

\author{
STEFFEN G. BERGH AND ARILD ANDRESEN
}

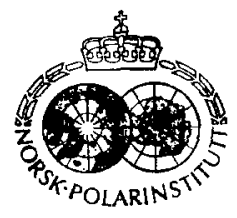

Bergh, S. G. \& Andresen, A. 1990: Structural development of the Tertiary fold-and-thrust belt in cast Oscar II Land, Spitsbergen. Polar Research 8, 217-236.

The Tertiary deformation in east Oscar II Land, Spitsbergen, is compressional and thin-skinned, and includes thrusts with ramp-flat geometry and associated fault-bend and fault-propagation folds. The thrust front in the Mediumfjellet-Lappdalen area consists of intensely deformed Palcozoic and Mesozoic rocks thrust on top of subhorizontal Mesozoic rocks to the east. The thrust front represents a complex frontal ramp duplex in which most of the eastward displacement is transferred from sole thrusts in the Permian and probably Carboniferous strata to roof thrusts in the Triassic sequence. The internal geometrics in the thrust front suggest a complex kinematic development involving not only simple 'piggy-back', in-sequence thrusting, but also overstep as well as out-of-sequence thrusting. The position of the thrust front and across-strike variation in structural character in east Oscar II Land is interpreted to be controlled by lithological (facies) variations and/or pre-existing structures, at depth. possibly extensional faults associated with the Carboniferous graben system.

Steffen G. Bergh, Institute of Biology and Geology, University of Troms $\phi, N-9001$ Troms $\phi$, Norway; Arild Andresen, Institute of Geology, University of Oslo, P.O. Box 1047 Blindern, 0316 Oslo 3, Norway; July 1989 (revised May 1990).

The western margin of Spitsbergen, with its Tertiary deformation structures including en echelon folds, strike slip faults and local extensional features, has been considered the type area for transpressive deformation (Orvin 1940; Harland 1969; Birkenmajer 1972; Lowell 1972; Harland \& Horsfield 1974; Kellogg 1975; Steel et al. 1985). These structures are considered to have been formed by dextral transform movement of Greenland relative to Spitsbergen during the opening of the North Atlantic and Arctic Oceans in the Eocene (Myhre et al. 1982; Eldholm et al. 1987). Recent structural data, however, indicate that Tertiary compressional stresses were transferred eastwards across most of Spitsbergen, producing a foreland fold-andthrust belt (Dallmann et al. 1988; Andresen et al. 1988a, b; Bergh et al. 1988a, b; Nøttvedt et al. 1988; Maher 1988a, b). Compressional structures have been documented as far east as Storfjorden (Fig. 1). The transfer of Tertiary compressional stresses to these easternmost areas was largely accomplished by the formation of décollement zones in pre-Tertiary strata, e.g. Paleozoic and Mesozoic shaly and evaporite horizons (Andresen et al. 1988a, b; Bergh et al. 1988a, b; Haremo et al. 1988; Haremo \&
Andresen 1988; Harland et al. 1988; Nøttvedt et al. 1988).

Due to a regional southward plunge of the post-Caledonian sedimentary strata in central Spitsbergen, structurally deeper décollement zones are exposed in a north-south traverse. Décollement zones in the Paleozoic evaporite sequences are exposed only in Oscar II Land north of Isfjorden (Fig. 1).

The main structural features associated with the fold belt north of Isfjorden have been described by Holtedahl (1913), Orvin (1934, 1940), Challinor (1967), Lowell (1972), Harland \& Horsfield (1974) and Maher (1988a, b). In a comprehensive description of the area around Isfjorden Orvin $(1934,1940)$ pointed out notable differences in the tectonic development of the West-Spitsbergen Orogenic Belt north and south of Isfjorden. Whereas the area to the south is dominated by a simple mode of deformation with a few ENE-directed reverse faults and open folds, the deformation to the north of Isfjorden is more complex, with tight folds and numerous reverse faults. This structural characterization was confirmed by Challinor's (1967) work on Brøggerhalvøya. Harland \& Horsfield (1974) distinguished a fold-and-thrust domain in central 


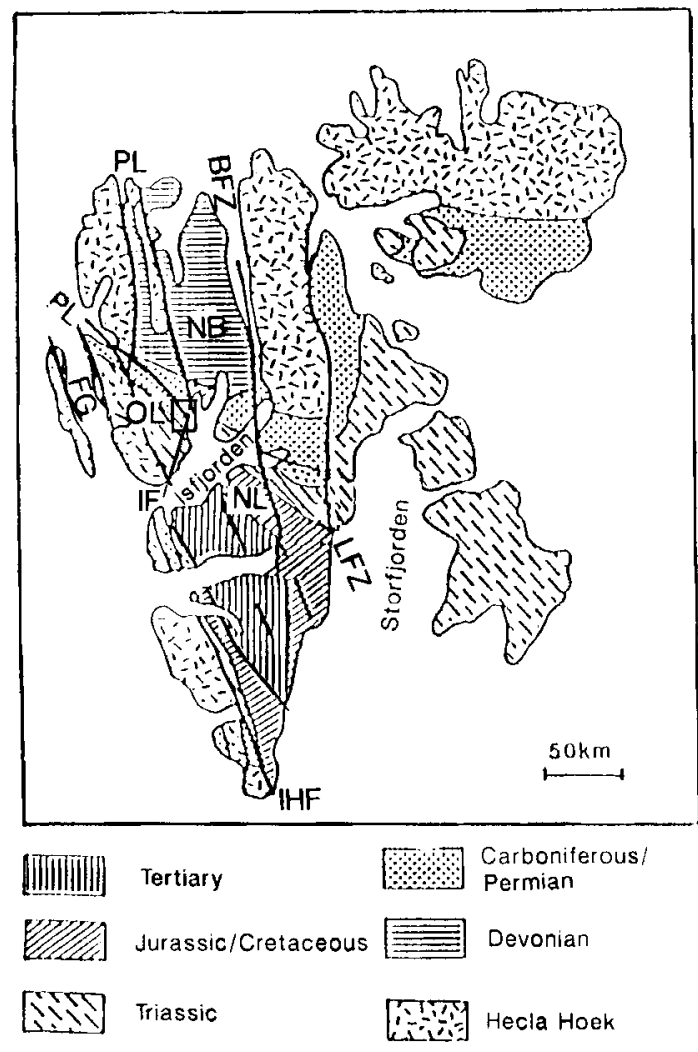

Fig. I. Simplificd geologic map of Spitsbergen showing the distribution of the main rock provinces and major tectonic lincaments. The studied area (Fig. 2) is framed. BFZ= Billefjorden Fault Zone, FG = Forlandsundet Graben, IHF = Inner Hornsund Fault, IF = Isfjorden Fault, LFZ = Lomfjorden Fault Zone, NB = Nordfjorden Block, NL $=$ Nordenskiöld Land, OL = Oscar II Land, PL = Pretender Lineament

Oscar II Land, bordered to the east by the Lappdalen thrust and to the south by the Isfjorden fault, an inferred SW-NE oriented dextral strikeslip fault (Fig. 1). Both Lowell (1972), Kellogg (1975) and Harland \& Horsfield (1974) emphasized the greater width of the Tertiary foldbelt north of Isfjorden relative to the area south of Isfjorden. Lowell (1972) related this along-trend variation in structural style to a more extensive development of Permian gypsum horizons in the north, whereas Harland \& Horsfield (1974) attributed the greater width of the deformation to NE-directed dextral strike-slip movement along the Isfjorden fault. Orvin (1940) considered the widening of the orogenic belt north of Isfjorden to possibly be an effect of less overburden here than in the Central Tertiary Basin to the south.
Recent field investigations (Bergh et al. 1988a, b) and complementary photo interpretation analysis (Maher 1988a, b) in Oscar II Land have demonstrated that the deformation is typically thin-skinned. These authors subdivided the region into domains of distinctive structural modes from west to east, including: 1) a westernmost zone characterized by major, east-verging folds overlying steeply dipping, basement-rooted thrusts, 2) a central zone of folded Paleozoic and Mesozoic strata above a subhorizontal detachment horizon in Permian gypsum, 3) an eastern zone consisting of a thrust front, the LappdalenMediumfjellet thrust front, where Paleozoic and Mesozoic strata are thrust on top of more or less flatlying Mesozoic rocks of the Nordfjorden Block (Bergh et al. 1988a, b).

The Lappdalen-Mediumfjellet thrust front in east Oscar II Land (Fig. 2; Bergh et al. 1988a, b) provides a unique section through the stack of thrust sheets, and thus allows one to establish a geometric relationship between the folding and thrusting. This relationship is of crucial importance in order to understand the kinematics of Tertiary deformation in the foreland carapace of WestSpitsbergen, which in turn is critical for crosssection restoration. The purpose of this paper is: a) to investigate the variation in structural modes across the thrust front, b) to study the age as well as geometric and kinematic relationships between folding and thrusting in the area, c) to discuss these relationships in relation to previous models proposed for this part of the fold belt. We furthermore attempt to discuss the probable relationship between the thrust front and some of the other major pre-Tertiary structural features in Spitsbergen, including the Carboniferous extensional faults.

\section{Stratigraphy and basinal configuration}

The lithostratigraphic succession of western and northern Oscar II Land consists of Precambrian Hecla Hoek and Devonian rocks (Fig. 1). Here, these 'basement' strata are brought into tectonic contact with the Paleozoic (CarboniferousPermian) and Mesozoic (Triassic) foreland strata of central Oscar II Land (Ohta 1988; Fig. 1). In central Oscar II Land the Permian and Mesozoic platform succession is considered to be underlain by thick Carboniferous clastic rocks belonging to 


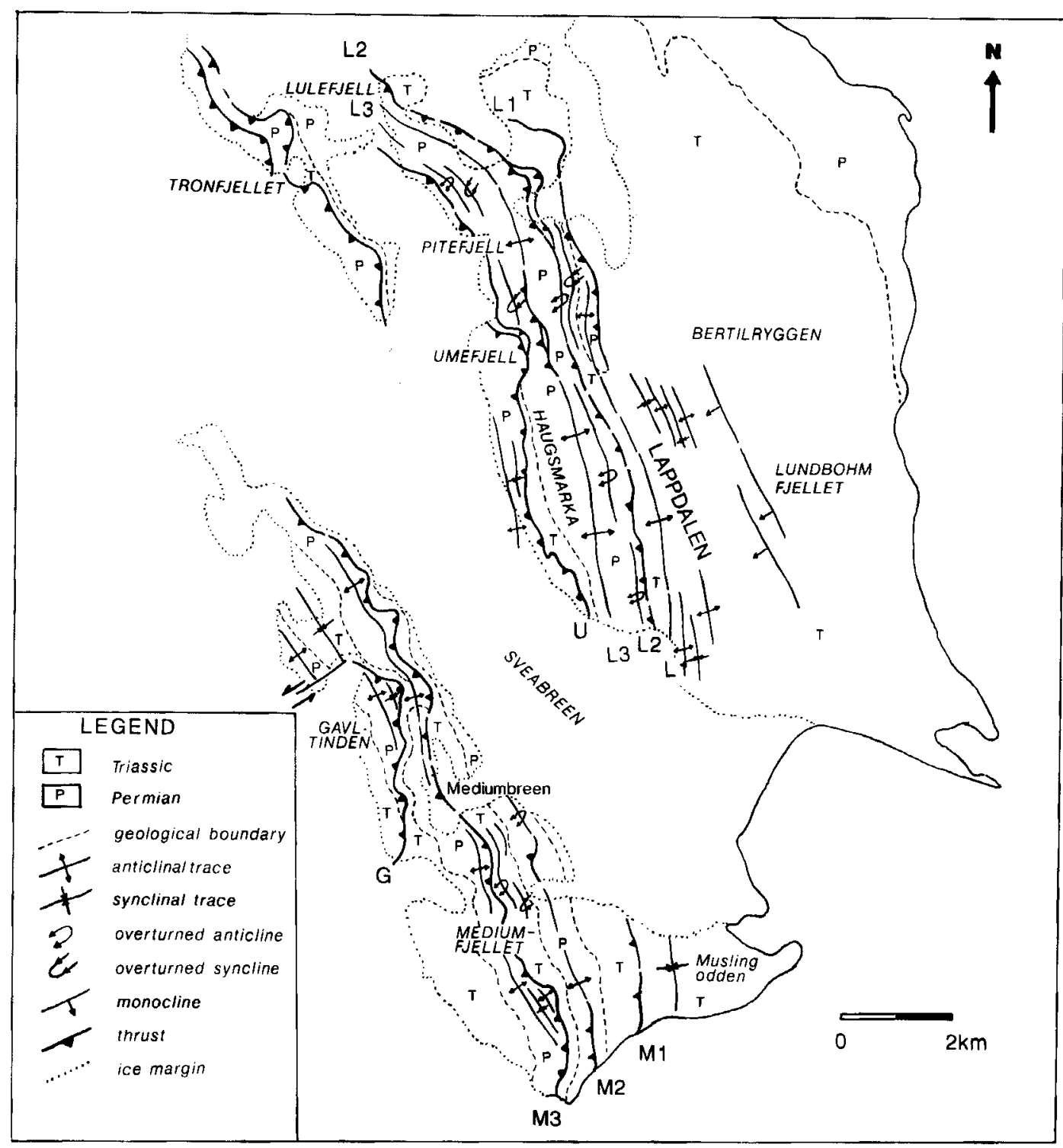

Fig. 2. Tectonic map showing the main structural features (folds and thrusts) in the Mediumfjellet-Lappdalen area.

the St. Jonsfjorden Trough (Fig. 3; Steel \& Worsley 1984; Steel et al. 1985). The folded and imbricated platform sequence at Lappdalen (Fig. 2) is underlain by Mesozoic and Upper Permian units, the latter unconformably overlying Devonian rocks of the Nordfjorden Block (Fig. 1). The St. Jonsfjorden Trough is interpreted as one of a series of NW-SE-oriented 'en echelon' southward migrating basins (Fig. 3) developed at high angle to the major Hornsund sinistral strike slip fault (Harland \& Horsfield 1974; Mørk et al. 1982; Steel \& Worsley 1984). These early-midCarboniferous basins were controlled by preexisting normal faults, ranging in age from Precambrian to Devonian. Of particular interest to our work is the Pretender Lineament (Harland \& Horsfield 1974; Steel \& Worsley 1984), inferred from sedimentological and seismical analyses to represent the down-and-to-the-west-faulted margin of the Nordfjorden Block (Fig. 3). This 


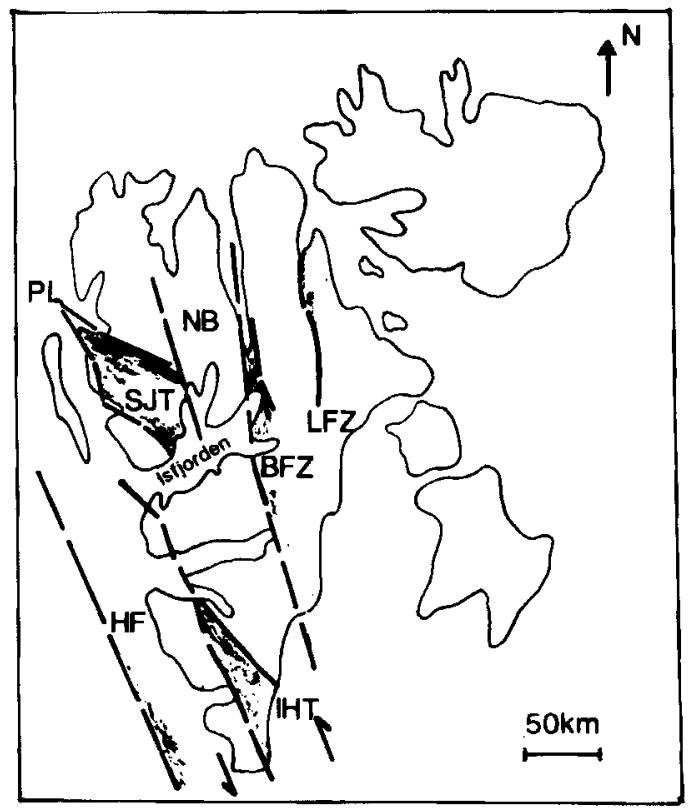

Fig. 3. Sketch map showing the position of en echelon Carboniferous basins and their bordering normal faults as inferred by Steel \& Worsley (1984). PL = Pretender Lineament, SJT = St. Jonsfjorden Thrust, NB = Nordfjorden Block, BSZ = Billefjorden Fault Zone, LFZ = Lomfjorden Fault Zone, HF = Hornsund Fault, IHT = Inner Hornsund Fault.

border fault appears to coincide geographically with the Mediumfjellet-Lappdalen thrust front (Fig. 2).

The stratigraphy of the platform sequence in the study area is shown diagrammatically in Fig. 4. The lowermost exposed portion of the sequence includes Middle Permian evaporites (Gipshuken Formation) overlain by various silicified carbonates and minor shales (Kapp Starostin Formation) and then by Triassic strata, predominantly shales and minor siltstones and sandstones. Older rocks are not exposed along the studied traverse but outcrop further to the north and west.

\section{Structural geology}

The Mediumfjellet-Lappdalen thrust front is characterized by a gently westward-dipping, stacked and imbricated sequence (Fig. 2). Several thrust sheets, each separated by distinct thrusts or major fold and fault zones (termed L1-3, M13, $G$ and $U$ in Fig. 2), are easily recognized on the basis of repetitions of the Permian Kapp Starostin and Gipshuken Formations and lower Triassic units. Based on along-strike extrapolation and aerial photograph interpretations, it seems clear that the thrust sheets making up Mediumfjellet occur at a structurally higher level than those in Lappdalen. A major thrust at Tronfjellet (Fig. 2), seen on aerial photographs and positioned above the Lappdalen thrusts, may correlate with the lowermost Mediumfjellet thrusts.

The internal deformation within the individual thrust sheets varies stratigraphically as well as laterally along strike. A commonly observed feature is that single thrusts and imbrications pass laterally into asymmetric folds of variable size and geometry. The geometry of these folds appears to change from north to south as a result of changes in lithology and vertical-lateral changes in structural mode. Folds developed in incompetent Triassic units are typically disharmonic and upright in character, and have small wave-lengths, while folds in the competent Permian strata display typical chevron and boxlike geometries and have larger amplitudes and wavelengths. The folds in general plunge towards SSE, causing successively lower stratigraphic levels to be exposed when moving northward. The strike of the thrust front changes from NNWSSE in southern areas to a NW-SE orientation north of Pitefjell (Fig. 2).

At least two regionally extensive décollement zones exist within the Upper Paleozoic and Mesozoic platform sequence of Oscar II Land. The lower zone is situated within the weak and ductile anhydrite/gypsum layers of the Gipshuken Formation and the upper zone in shaly Mesozoic sequences, particularly in the Triassic Botneheia Member (Fig. 4). The Gipshuken Formation shows strong internal deformation in the form of disharmonic folding and local thickening due to imbricate faulting, whereas subjacent beds display much less deformation. The evaporite unit clearly acted as a slip zone for bedding-parallel movements between the competent Permian carbonate rocks. Similarly, strong internal deformation, characterized by low angle to subhorizontal reverse faulting and folding, is observed in the shaly Triassic Deltadalen and Botneheia Members (Fig. 4) in the easternmost study areas. On the basis of the stratigraphy within and geometry between the thrust sheets it appears that the Gipshuken Formation acted as a sole thrust and that a roof thrust existed in the 


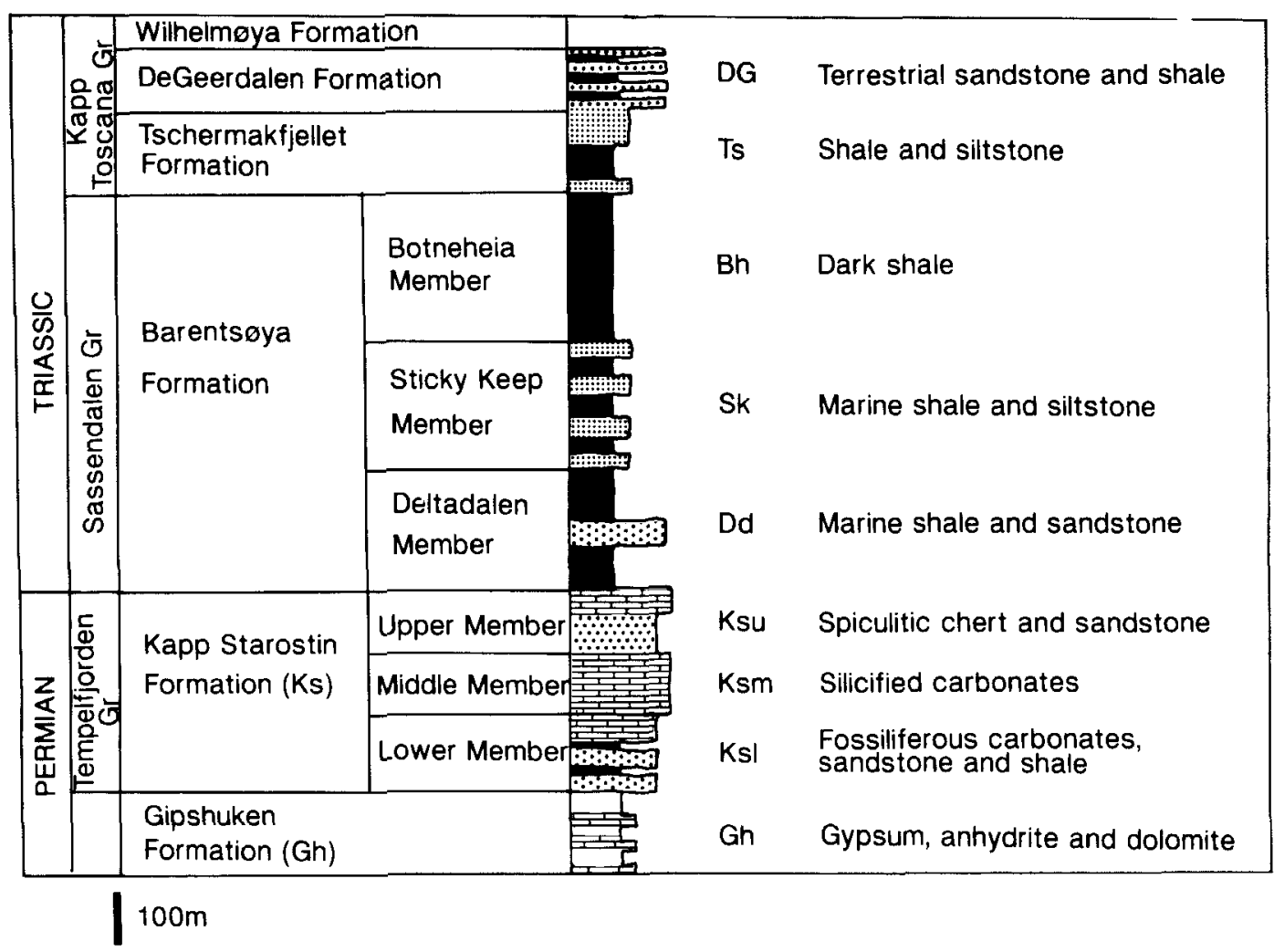

Fig. 4. Simplified lithostratigraphic column of the Permian and Triassic strata in the studied area. The various patterns are the same as those used on the geological maps and cross sections (Figs. 2, 5 and 7).

shaly lower part of the Triassic sequence. The existence of a possibly deeper décollement zone, e.g. in the Carboniferous strata of Oscar II Land, is inferred from observations further west and north, where Carboniferous rocks are detached from the Hecla Hoek basement and involved in the folding and thrusting (Orvin 1940; Challinor 1967; Maher 1988a, b).

An overview from east to west, in ascending order of the main folds and thrusts associated with the Mediumfjellet-Lappdalen thrust front (Fig. 2), is presented below. A kinematic analysis of their mode of origin follows.

\section{Lappdalen transition zone}

The transition zone refers to the area located between the flatlying strata east of Bertilryggen and the heavily faulted and folded Permian and Mesozoic strata west of Lappdalen (Figs. 2 and $5)$. The zone is approximately $2 \mathrm{~km}$ broad and comprised of abundant mesoscale folds and several west-facing monoclines. Most of the folds in the Triassic strata display tight, asymmetric geometries and face east, with steep, westwarddipping to near upright axial planes. Folds in the Kapp Starostin Formation have a characteristic staircase and box fold geometry. Two monoclines, displaying an estimated $100 \mathrm{~m}$ down-and-to-thewest throw of the Botneheia Member, are observed west of Lundbohmfjellet (Fig. 5a).

\section{The Lappdalen fold-and-thrust zones}

The major thrust front west of the transition zone in Lappdalen is composed of at least four distinct thrusts or fold structures (L1, L2, L3 and U), as illustrated on the map and cross sections (Figs. 2 and $5 \mathrm{a}, \mathrm{b}$ ). All four thrusts are accompanied by large- and small-scale fold structures in the hangingwall as well as in the footwall strata. The structurally lowest and easternmost thrust, L1, which marks the boundary to the transition zone, outcrops southeast of Pitefjell in the core of a 


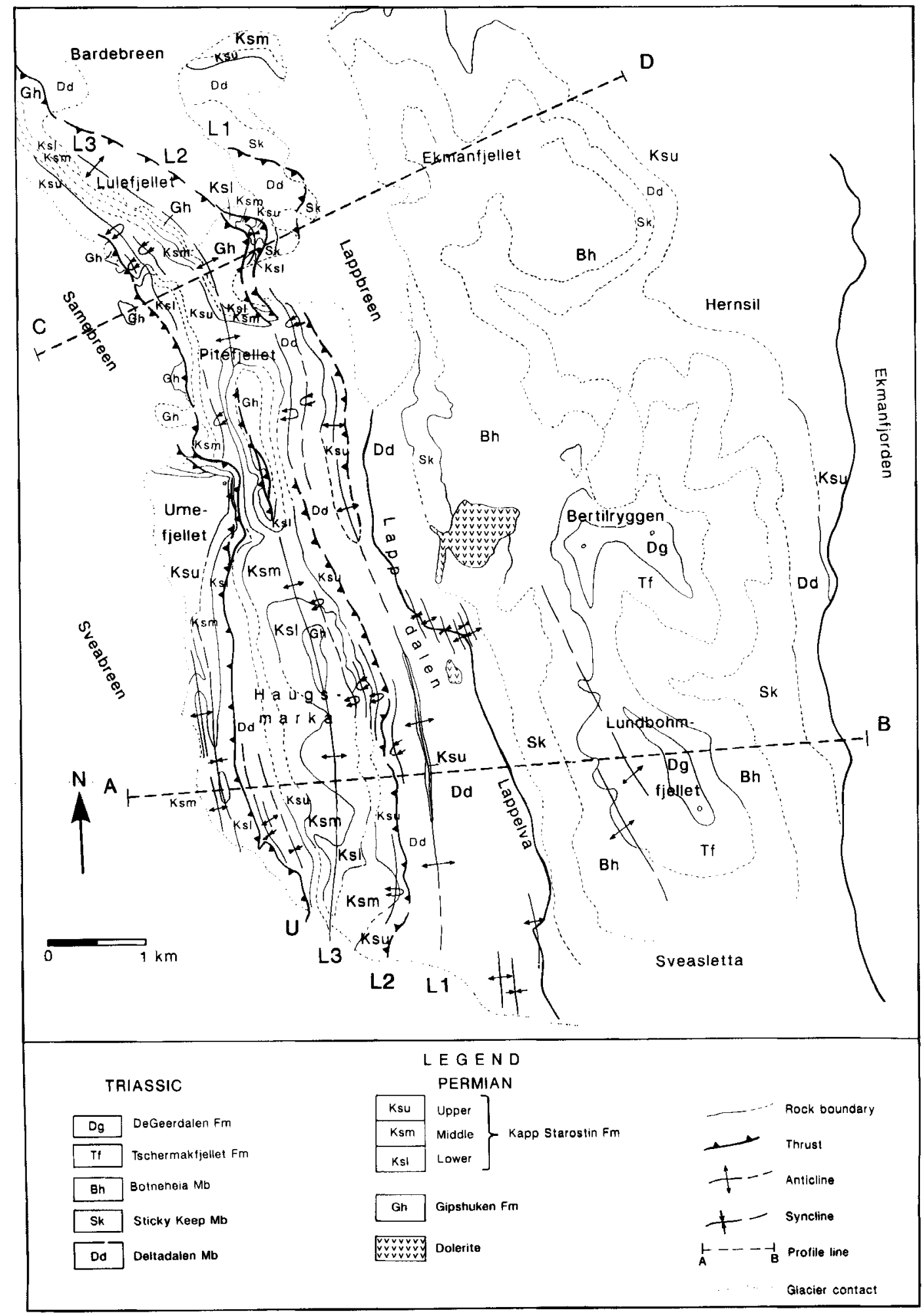




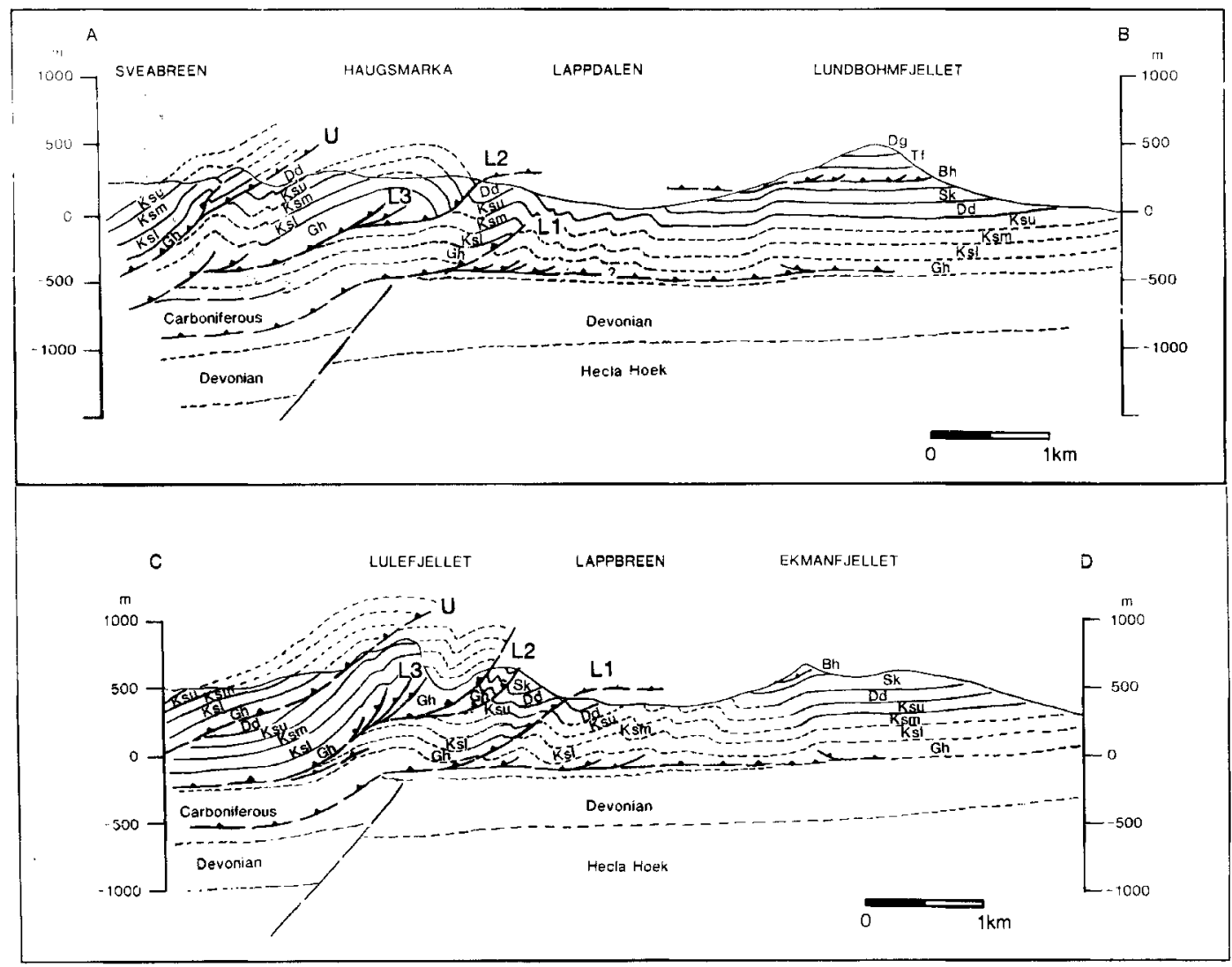

Fig. $5 b$.

major NNW-SSE trending kink/chevron type anticline with a vertical eastern forelimb (Fig. 5a, b). This forelimb is cut by the L1 thrust, which dips $\mathbf{4 0}$ degrees to the west in the northern areas (Fig. 5b, Section C-D). The thrust passes into a near symmetric, open anticline southward along strike, before dying out in the folded Lower Triassic (Deltadalen) members. This indicates that the L1 thrust either ends in a tip line in the overlying Triassic units (Fig. 5b, Section A-B), or continues as a flat eastwards within Triassic shales (Fig. 5b, Section C-D).

The L2 thrust cuts the backlimb of the fold associated with L1 (Fig. 5). L2 appears to have a listric geometry; it dips gently westwards and displaces the lower KappStarostin and Gipshuken Formations of the hanging wall above the folded Triassic strata of the footwall (Fig. 5). East of Haugsmarka (Fig. 5b, Section A-B) L2 occurs as a single thrust, whereas further north it splits into two or more splay faults (Fig. 5b, Section C-D). At both localities the $\mathrm{L} 2$ thrust makes an angle of approximately 90 degrees relative to bedding in the hangingwall. Displacement across the L2 thrust is approximately $100 \mathrm{~m}$. A characteristic feature observed at Lappbreen (Fig. 5a) is that parasitic folds are developed up-section in front of small-scale splay faults of the hangingwall block, forming a typical imbricate fan. Also, Lower Triassic shales and siltstones of the footwall block are strongly folded and disrupted by minor shear zones.

The structurally higher $\mathbf{L} 3$ thrust is well exposed east of Pitefjell and Umefjell (Fig. 5a), where it outcrops in the eroded core of a major, composite kink anticline, termed the Haugsmarka Anticline (Fig. 6a). It can be traced along the entire length of the thrust front. The Haugsmarka Anticline

Fig. 5. Geological map (a) (above) with cross sections (b) (opposite page) of the Lappdalen area. L1, L2, L3 and U refer to major fold-and-thrust zones described in the text. 
displays a maximum wavelength of $1.5 \mathrm{~km}$; it has a vertical forelimb, a steep WSW-dipping axial plane and a SSE-plunging fold axis. It includes several asymmetric to overturned parasitic chevron folds on its eastern limb (Fig. 6b), all of which are cut by the L2 thrust. The evaporite layers of the Gipshuken Formation just above the L3 thrust are characterized by numerous minor reverse faults (imbrications) and shear zones. The L3 fault which is located at the base of the Gipshuken Formation cuts steeply upsection as it approaches the Haugsmarka Anticline, where it dies out (Fig. 5). At Umefjell and Pitefjell (Fig. 5a) a variety of mesoscale, disharmonic folds and reverse faults are seen in the evaporite unit (Fig. 6c). Here, it is tectonically thickened to $300 \mathrm{~m}$, which is almost three times the thickness of the stratigraphy observed further east and west. This thickening is most likely due to layer parallel shortening and small-scale imbrication of the incompetent evaporite material in the fold hinge zone. Further to the east the L3 thrust truncates beds of the lower Kapp Starostin Formation present in the forelimb of the Haugsmarka Anticline.

The structurally highest thrust in the Lappdalen area is the Umefjellet thrust (U, Figs. 2 and 5a). It differs from the other thrusts in that it cuts down-section in the direction of tectonic transport, at least locally (Fig. 5b, Section C-D). The crosscutting relationship between this thrust and the underlying Haugsmarka Anticline of its footwall (Fig. 6d) can be seen north of Umefjellet and in the Haugsmarka area (Fig. 5a), where it cuts slightly down-section from the folded Deltadalen Member into the upper level of the Kapp Starostin Formation (Fig. 5b, Section C-D). Minor folds and related splay faults occur in the hangingwall. The Umefjellet thrust is developed in a zone of disrupted evaporite layers which vary in thickness from 10 to $40 \mathrm{~m}$ along strike. A reliable estimate of displacement along this fault cannot be provided, as no comparable hanging- and footwall cutoffs are preserved. However, a minimum displacement of $1 \mathrm{~km}$ is inferred from the crosssection.

\section{The Mediumfjellet fold-and-thrust zones}

A geological map and cross-sections of the Mediumfjellet area are presented in Fig. 7a and b. Four prominent thrusts, M1, M2, M3 and G (Figs. 2 and 7), outcrop in the area. The easternmost areas, near Muslingodden (Figs. 2 and 7), consist of almost flatlying shaly units of the Botneheia Member (Fig. 7). Mapping along the shore in this area revealed a zone of high strain (M1) characterized by imbrication and subhorizontal cleavage development. Within a short distance westward these flatlying strata are overlain by steeply dipping, partially overturned Triassic strata belonging to the eastern forelimb of a major asymmetric anticline (Figs. 2, 7 and 8). These steep to overturned strata are interpreted to be located structurally above a hangingwall cutoff, representing the M1 thrust (Figs. 7 and 8). The high strain zone typical of the subhorizontal strata of the footwall suggests that it represents a flat thrust (Fig. 7b, Sections A-B, C-D and E-F).

A prominent anticline occurs in the hangingwall to M1 (Fig. 7b). Mapping northward along strike demonstrates that this fold is cored by a zone of westerly dipping, thickened and highly deformed Permian gypsum-anhydrite strata. The M2 fault is inferred to end as a tip line in the core of the anticline.

The westernmost and uppermost thrust (M3) on Mediumfjellet is also developed as a flat in the Gipshuken Formation (Fig. 8). It cuts steeply up-section through moderately westerly dipping Permian and Triassic units of the footwall block, and emplaces the Gipshuken Formation on top of Triassic strata (Fig. 8). Several minor faults splaying off from the M3 thrust cut up-section into the overlying, competent Kapp Starostin Formation of the hangingwall (Fig. 8). Most of these faults are planar, with decreasing displacement upwards, and they generally end in a fold (Fig. 8). Some of the minor folds towards the mountain top of Mediumfjellet appear to be parasitic structures related to a major anticline developed in the hangingwall block to M3 (Fig. 8). Many of these hangingwall folds display asymmetric, tight chevron and box fold geometries (Fig. 9a), often with overturned thinned easterly limbs, shallowly SSE plunging axes and steep (450) westward-dipping axial planes. The M3 thrust and associated splay faults cut the overturned forelimbs at an angle of approximately 65 degrees (Fig. 7b, Section A-B). Minimum displacement along the M3 thrust is estimated to be $700 \mathrm{~m}$ on the southern slope of Mediumfjellet. Further north, where it cuts up into the Triassic shales, M3 splits into several minor faults, with an imbricate fan geometry (Fig. 7 b, Sections C- 
Structural development of the Tertiary fold-and-thrust belt 225
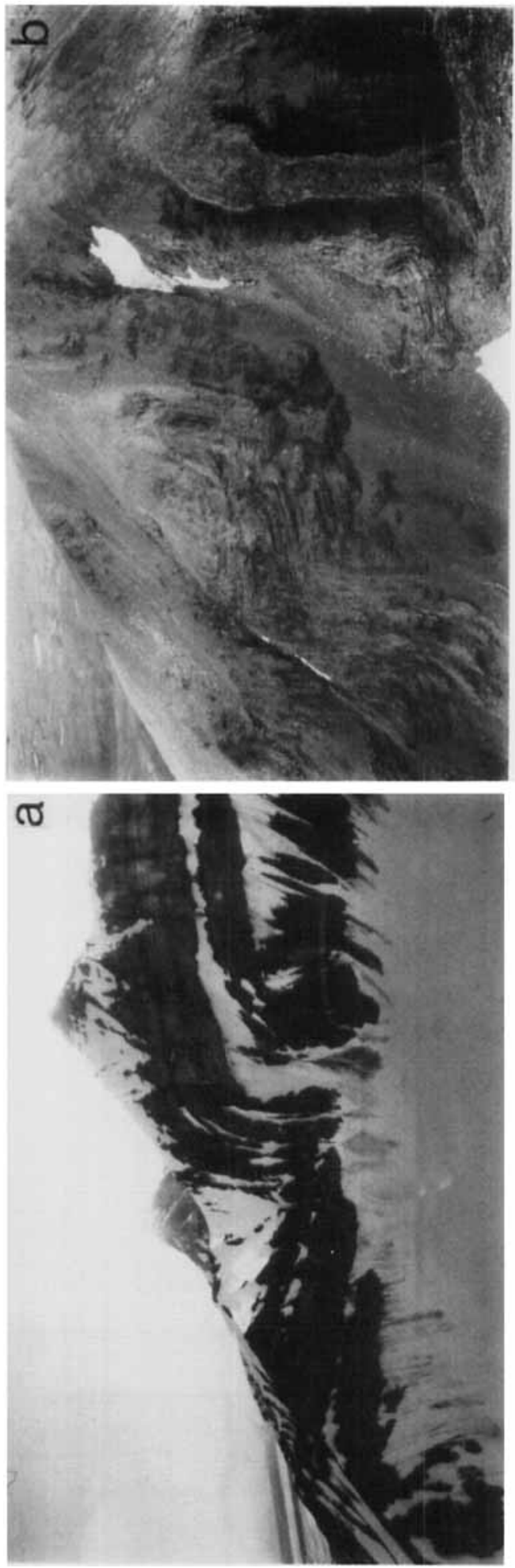
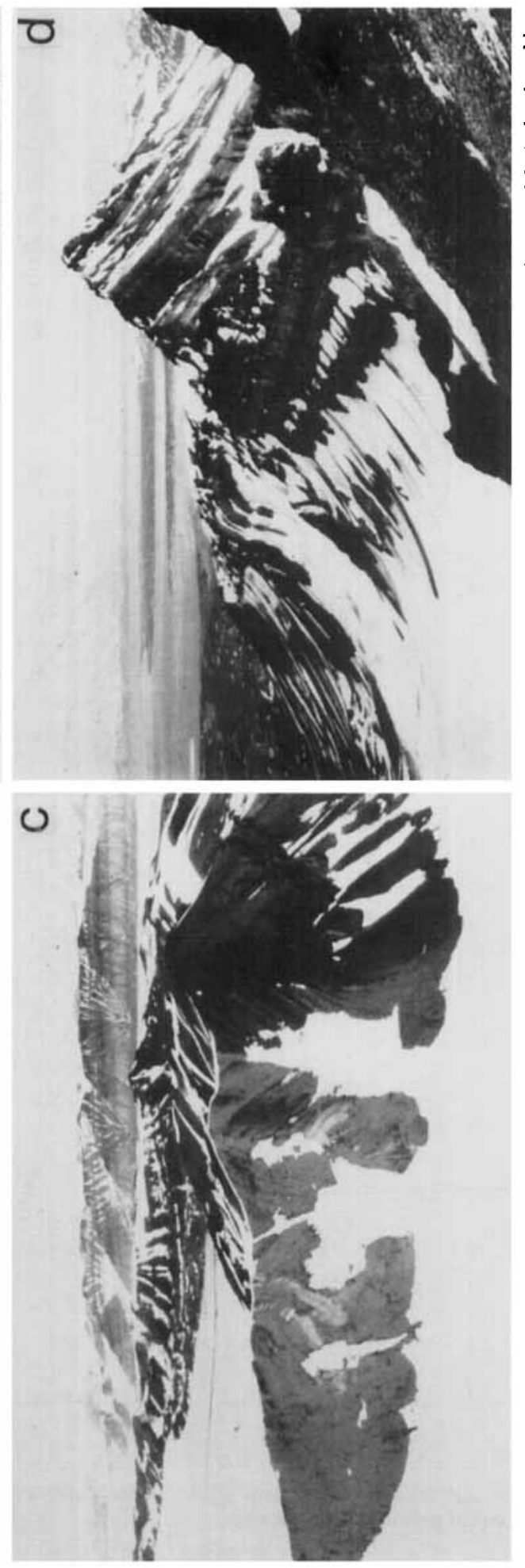

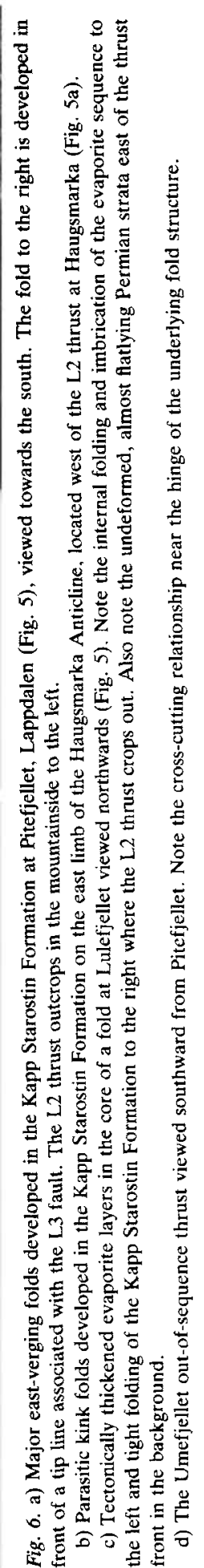




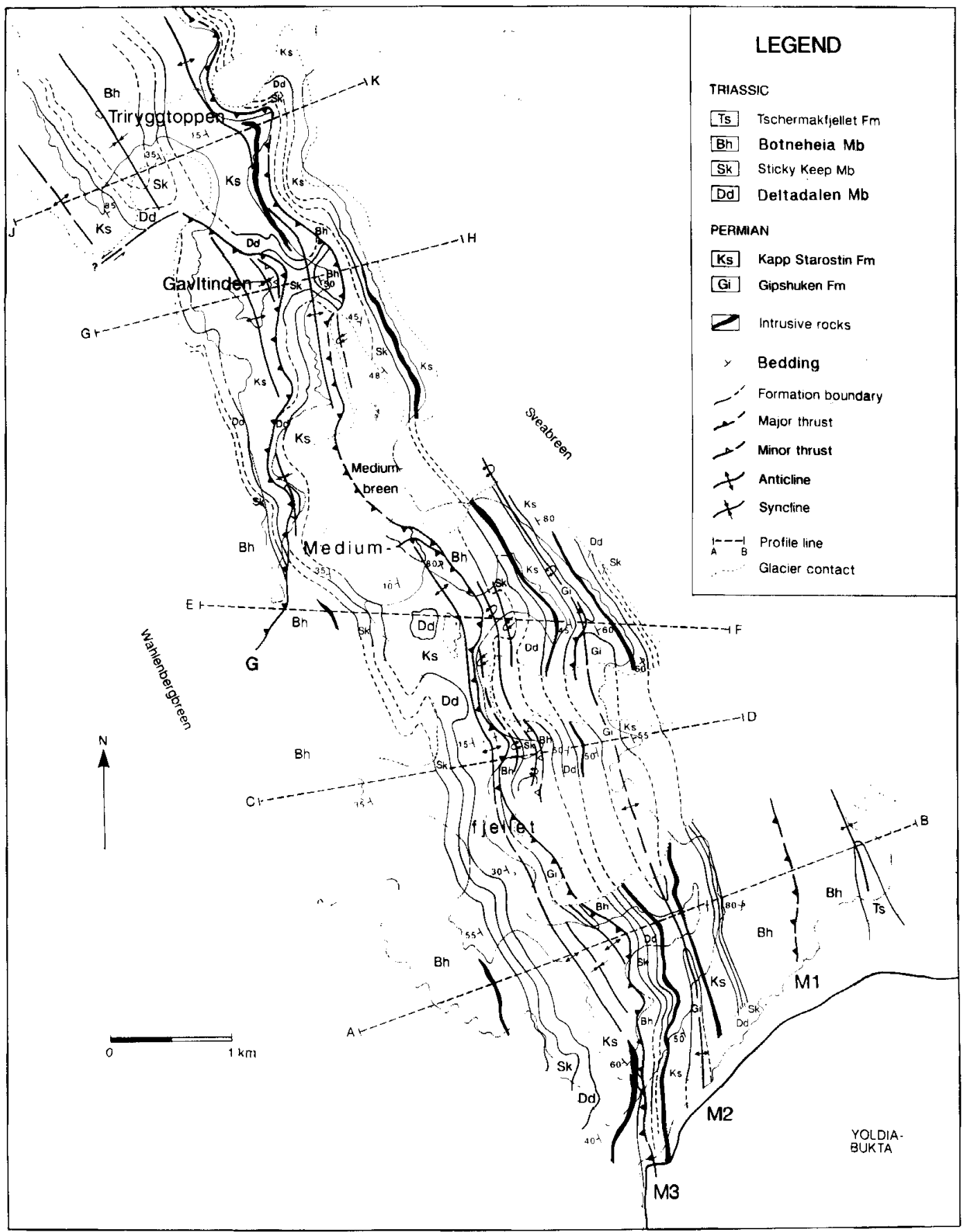

a

Fig. 7. Geological map (a) with cross sections (b) of the Mediumfjellet area. M1, M2, M3 and G refer to the major fold-andthrust zones described and discussed in the text. 


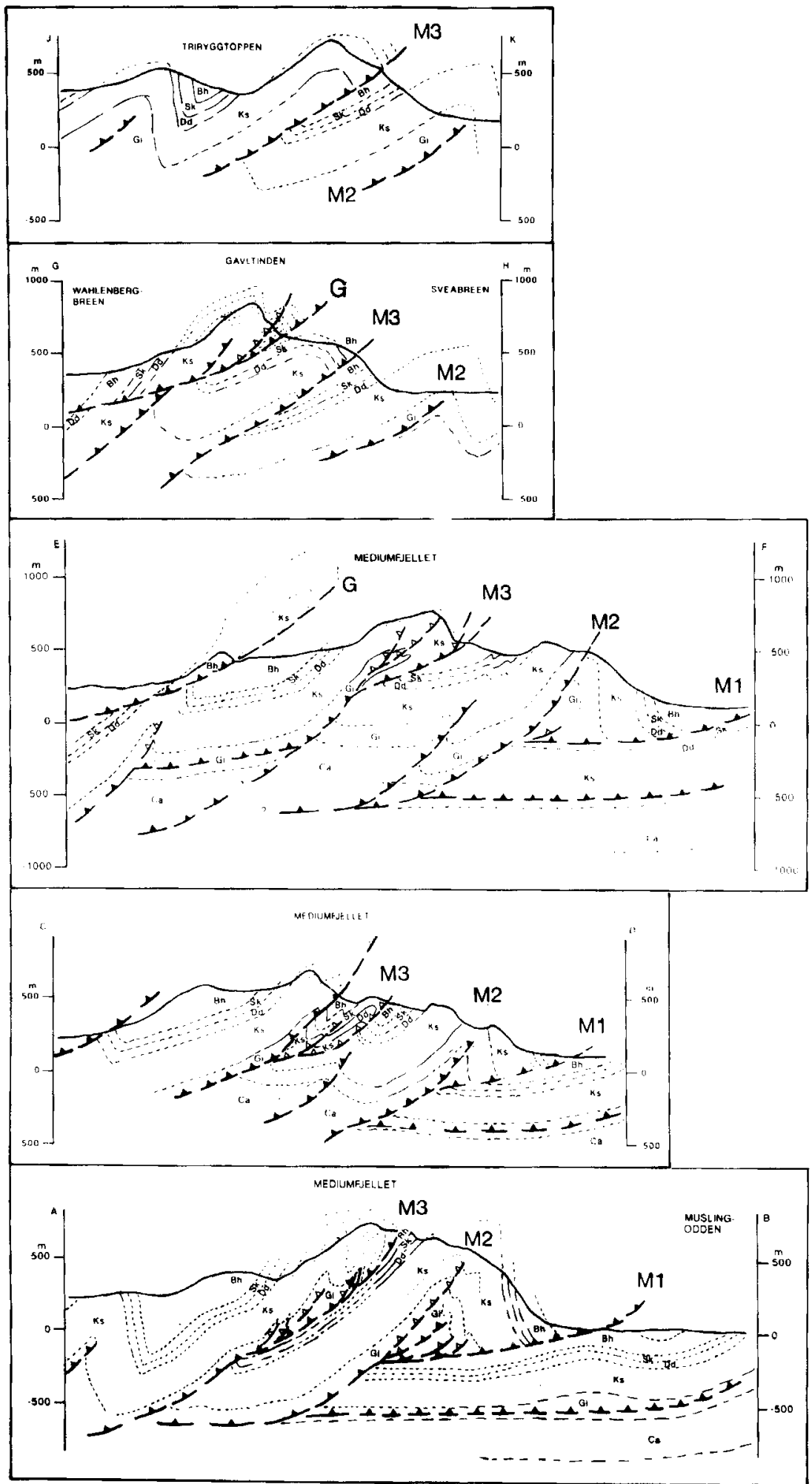

b 

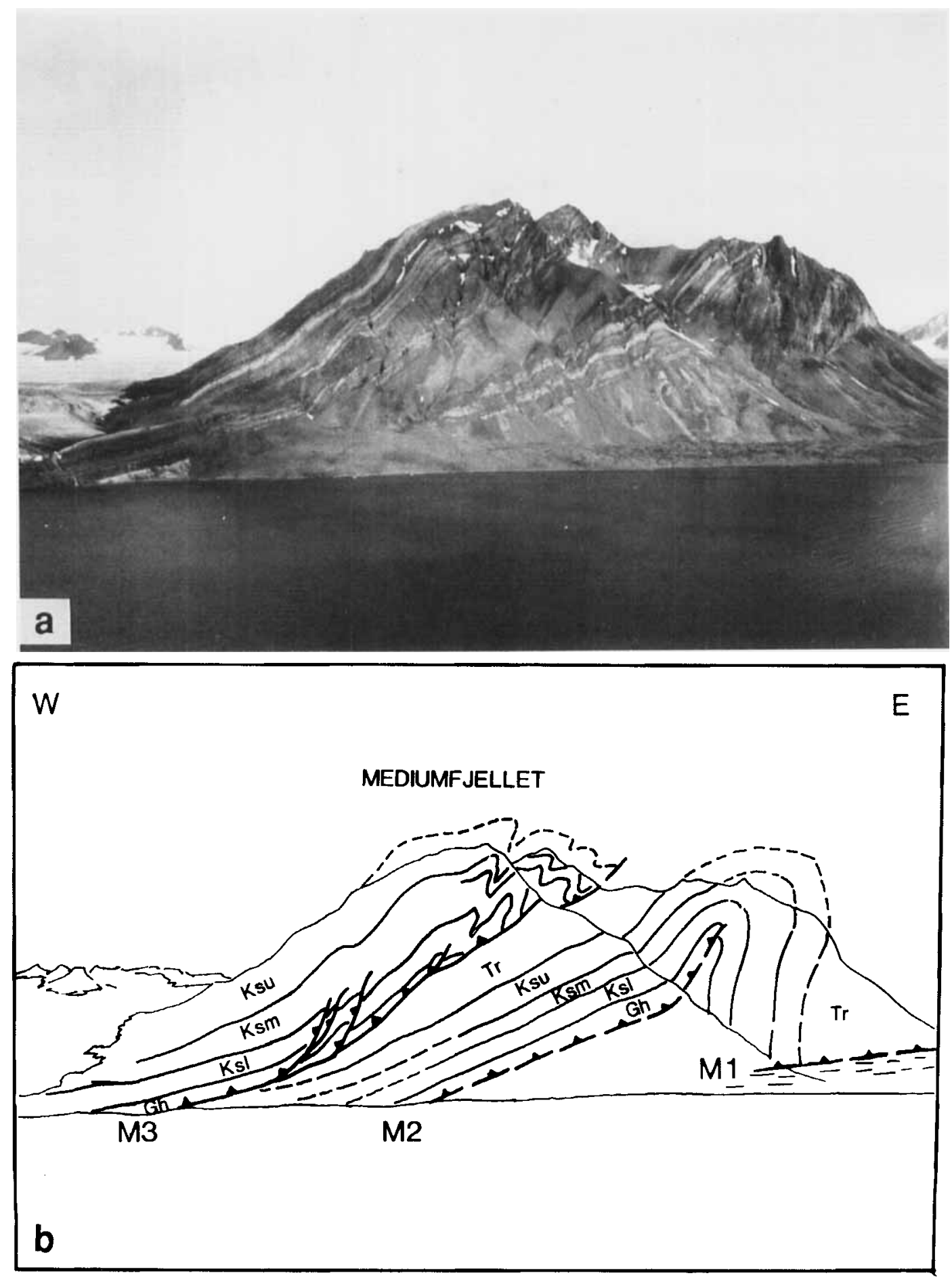

Fig. 8. a) Mediumfjellet, viewed from the south. b) Structuíd interpretation of Mediumfjellet, showing the major thrusts (M1, M2 and M3) and related fold structures. Tr = Triassic, Ksu = Upper Kapp Starostin Formation, Ksm = Middle Kapp Starostin Formation, $\mathrm{Ksl}=$ Lower Kapp Starostin Formation, $\mathrm{Gh}=$ Gipshuken Formation. 
Fig. 9. a) Tight, overturned folds in the hangingwall of the M3 thrust at Mediumfjellet, viewed southwards.

b) Southerly view of the major box-kink fold at Mediumbreen (Fig. 7), displaying vertical forelimb and gently west-dipping backlimb (to the right). Note the disharmonic folding of the anhydrite layers in the fold core.

c) Close up view of the forelimb in b), showing small scale folding and reverse faulting of the competent strata within the Kapp Starostin Formation. Note anhydrite layer in the fold core to the right.
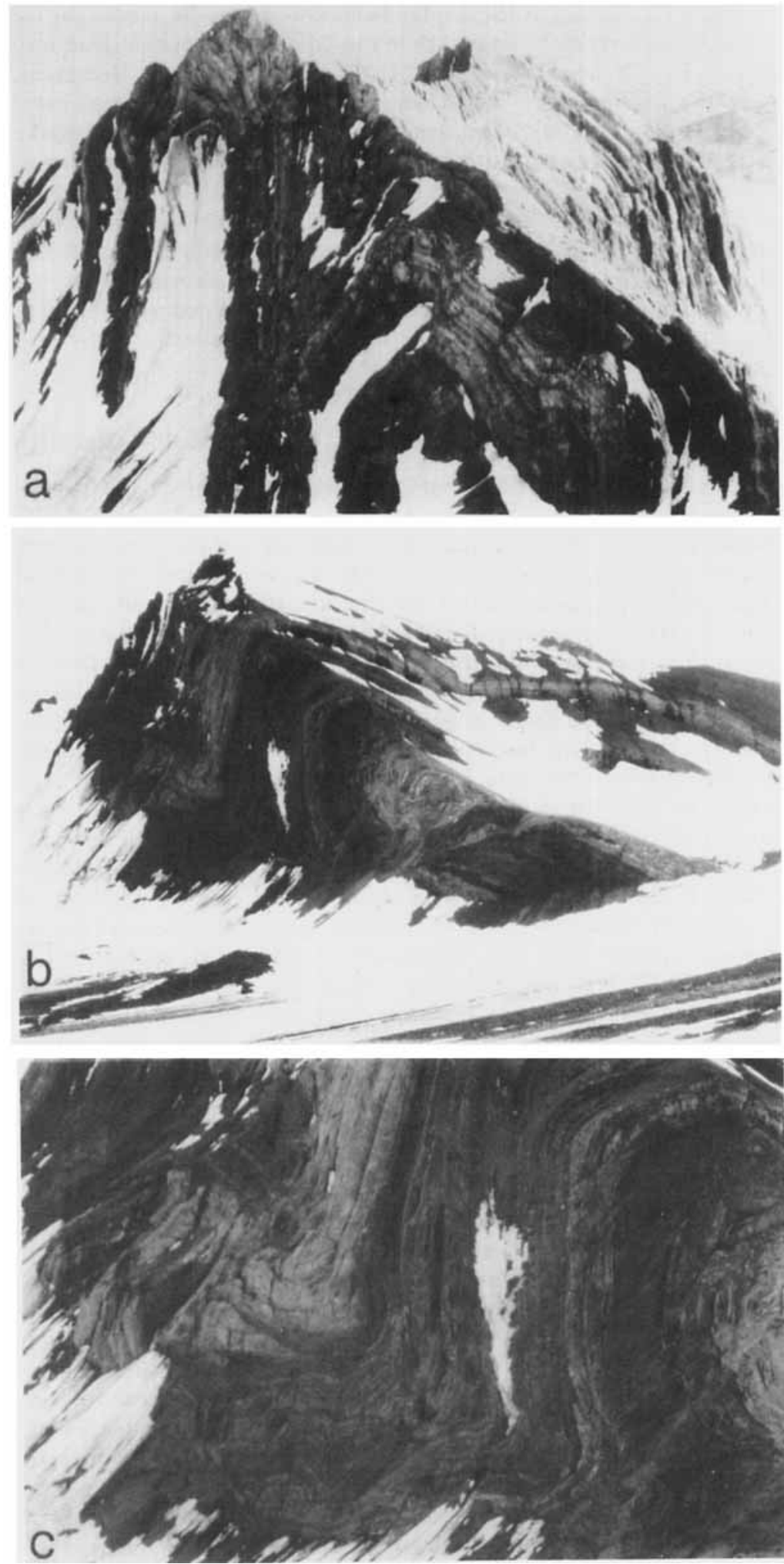
$D$ and E-F). Several of these splay faults end in strongly disharmonic to tight folds in the Triassic shales (Fig. 7b, Section C-D).

In the Mediumbreen area, $3 \mathrm{~km}$ northwards along strike (Fig. 7a), displacement on thrust fault M3 diminishes to less than $200 \mathrm{~m}$, based on footwall-hangingwall cut-off of the Gipshuken evaporite beds (Fig. 7b, Section E-F). At this particular locality the major hangingwall anticline is developed as a broad box/chevron-type fold, some $500 \mathrm{~m}$ in width in the upper part of Kapp Starostin Formation (Fig. 9b). The western fold limb dips gently westward whereas the forelimb is near-vertical and locally overturned. The forelimb is often thinned. The interlimb angle is approximately $60^{\circ}$ (Fig. 9b). The evaporite unit in the core of this major hangingwall anticline is characterized by disharmonic, easterly overturned folds (Fig. 9b, c) and numerous, shallowly westward-dipping shear zones. Locally minor splay faults from the M3 thrust are observed to ramp through competent beds and flatten in shaly horizons of the Kapp Starostin Formation (Fig. $9 c)$. A composite syncline with overturned and strongly attenuated limbs is observed in Kapp Starostin strata of the footwall (Fig. 9b).

The Gavltinden thrust (G, Figs. 2 and 7 ) is the sole thrust to the uppermost thrust sheet in the area and it dips $20-25^{\circ}$ to the west. The Gavltinden sheet is composed of an anticline-syncline pair. There is no evidence of these being foldpropagation folds developed in front of splay faults associated with the Gavltinden thrust. Instead they are interpreted as being the decapitated upper part of a fold system developed within the underlying thrust sheet exposed at Triryggtoppen further north (Fig. 7a). On the basis of these observations, the Gavltinden thrust is interpreted to be an 'out-of-sequence' thrust (Morley 1988).

The footwall cutoff line with respect to the M3 fold structure is recognized just west of Mediumbreen, giving a minimum horizontal displacement of about $1 \mathrm{~km}$. The Gavltinden thrust is not present in strata further north on Triryggtoppen.

\section{Shortening estimates}

The profiles across the thrust front from Lappdalen (Fig. 5b) to Mediumfjellet (Fig. $7 \mathrm{~b})$ represent an across strike distance of approximately $10 \mathrm{~km}$, and permit some constraints to be placed on estimates of shortening of the deformed platform strata during the Tertiary orogeny. Rough calculations of shortening based on bed length estimate of the Permian-Triassic boundary and marker beds within the lower Kapp Starostin Formation give a minimum shortening of $4 \mathrm{~km}$. This is a conservative estimate, since the slip accommodated by minor blind thrusts, hidden flats and out-of-sequence thrusts, as well as the uncertainty in correlation of strata across Sveabreen (Fig. 2) are not taken into consideration.

\section{Modes of fold-thrust generation}

A kinematic analysis of the deformation structures observed in the Mediumfjellet-Lappdalen thrust front must take into account a) the various fold geometries observed, b) the modes of fold-thrust interaction, including age-relationships between folds and thrusts. These observations are essential for trying to distinguish between fold categories, which usually develop in foreland thrust belts, i.e. fault-bend folds, fault-propagation folds and detachment folds (Boyer \& Elliott 1982; Schmidt \& O'Neill 1982; Suppe 1983; Williams \& Chapman 1983; Jamison 1987). The two former fold types commonly develop above thrust ramps. Faultpropagation folds develop contemporanously with and immediately above the ramp, e.g. at its termination (Jamison 1987), whereas fault-bend folds are formed above the underlying ramp and their geometry is controlled by ramp-height, ramp angle and amount of displacement (Suppe 1983; Mitra 1988). Detachment folds, in contrast, develop above a thrust propagating along a subhorizontal décollement and they are, accordingly, unrelated to ramps and flats.

The following observations demonstrate that the hangingwall anticlines developed in the Lappdalen and Mediumfjellet areas are related to ramps in the footwall: 1) the typical box or conjugate kinkfold geometries with steep, locally overturned and thinned forelimbs and gently dipping backlimbs (Suppe 1983; Jamison 1987), 2) associated hangingwall cutoffs of folds overlying little deformed, almost flatlying footwall strata, 3 ) the displacement on steeply dipping thrusts diminishing to zero in the cores of overlying anticlines, 4) overturned forelimbs cut by splay faults linked to the underlying thrust, producing imbricate fans in front of the major anticlines. 
Accordingly, we link the variably but steeply dipping thrusts L3, M3 and M2, which emplace stacked thrust sheets above less deformed footwall strata, to major footwall ramps (Figs. $5 \mathrm{~b}$ and $7 \mathrm{~b}$ ). The $\mathrm{L} 2$ and M1 faults, having gentle dips and separating almost flatlying footwall and steeplydipping hangingwall strata, are interpreted as footwall flats linking the major ramps (Figs. 5b and $7 \mathrm{~b}$ ). The $\mathrm{L} 1$ thrust can be interpreted in two ways: 1) either as a flat linked to the L3 and L2 thrusts, or 2) as a separate, more easterly situated ramp developed in front of, or above a lower detachment. The latter interpretation is favored here on the basis of the present position, structural level and steep dip of the thrust (Fig. 5b). Thus, having identified major ramps and flats, the associated hangingwall anticlines represent either fault-bend or fault-propagation folds. The chevron fold with box geometry and forelimb hangingwall cutoff angles is consistent with a fault-bend mode of formation (Suppe 1983), as exemplified by the hangingwall folds of L3, M3 and M2. A faultpropagation fold mechanism is favored for some of the tight to overturned kink folds along M3 and L2, which have associated minor folds and imbrications in the footwall strata. A similar interpretation is envisioned for hangingwall structures showing contemporaneous development of folds and thrusts, i.e. where faults and imbrications die out in the fold cores (e.g. L3, L1, M3, M2) and where hangingwall anticlines die out or pass along strike into major thrusts.

Neither of the two kinematic end-member models seems to adequately explain the observed changes in fold geometry/structural style along strike of the same thrust, e.g. along M3 and L3. We consider the two fold-generating mechanisms to have operated interchangeably. For instance, the structurally upward tightening of some of the anticlines observed along M3 at Mediumbreen, possessing fault-propagation fold characteristics, may be explained by alternate rotation and flattening of a fault-bend fold due to westward tilting of the footwall brick and recurrent movement along the footwall ramp. A similar process also explains the oversteepening and reduction in thickness of strata in the forelimb of the hangingwall anticline at Mediumbreen (M3, Fig. 7b). Furthermore, a combined process of bed rotation with subsequent ductile shearing by movements along propagating thrusts initiating at the footwall ramp (Ramsay \& Huber 1987) could account for the imbrications cutting across footwall strata below the fold strueture at Mediumbreen. Shearing during ramp-flat thrusting could have produced footwall synclines typical of fault-propagation folds underneath the ramp of a fault-bend fold.

Knowledge of the sequential development of folds and thrusts is important for restoring the sedimentary sequence to its original predeformational geometry. Two fundamental modes of thrust propagation have been demonstrated (Elliott \& Johnson 1980; Butler 1982): 1) piggyback, or in-sequence thrusting, where thrusts propagate into the foreland, 2) overstep or backward migrating thrusting, where subsequent thrusts develop behind the thrust front and extend back into the tectonic hinterland. In general, but not universally, fault-bend and fault-propagation folds are considered the normal, or in-sequence, response to piggy-back thrusting (Suppe 1983). Accordingly, this implies that the westernmost Mediumfjellet thrusts (M1-M3) and associated hangingwall folds may have been modified by later thrust movement. They were probably first developed and later carried passively eastward by the lower Lappdalen thrusts (L1-L3). Within the studied areas there is a tendency for higher strain, as well as fold-and-thrust modification in the higher, western thrust sheets. Those observations suggest that the individual footwall blocks were tilted successively westward during foreland propagation of the underlying thrust(s).

On the other hand, some of the splay faults cutting up through the hangingwall from an underlying common ramp in the fold core and the accompanied tightening of typical fault-bend fold geometries, i.e. at Mediumfjellet (Fig. 9a) and Haugsmarka (L3), could be explained by thrust reactivation and overstep movement on the previously formed thrust ramps, e.g. during tilting of the footwall strata. Similar sequences of back-limb thrusting have been demonstrated by Jones (1984) from the Idaho-Wyoming Thrust Belt.

The structures proven to be out-of-sequence, i.e. the Gavltinden ( $G$ ) and Umefjellet (U) thrusts (Fig. 2), put further constraints on the relative timing and manner of thrusting in the Mediumfjellet-Lappdalen thrust front. The decapitated folds associated with these two thrusts indicate that these out-of-sequence thrusts postdate the fault bend- and fault-propagation folding and thrusting of the underlying strata. The Umefjellet thrust is similar to the fault-bend and 
fault-propagation fold-related thrusts in that it soles out in the Gipshuken Formation, but differs from the L1, L2, L3, M1, M2 and M3 thrusts by cutting down-section in the transport direction. This relationship suggests that displacement along the Umefjellet thrust may have succeeded the movement and folding along $\mathrm{L} 3$ and lower thrust. We thus suggest that the Umefjellet out-ofsequence thrust was formed by renewed (overstep) movements along the previously formed thrust ramps or detachments in the Permian evaporite layers.

The Gavltinden thrust, on the other hand, was most likely generated as an entirely new thrust, which cuts down-section at a low-angle and is unrelated to the pre-existing faults exposed at present.

\section{Kinematics of the Mediumfjellet- Lappdalen thrust front}

Geological features of importance for understanding the kinematics of the MediumfjelletLappdalen thrust front are: 1) the presence of décollement zones ramping up-section at different stratigraphic levels, 2) the overall stacked rampflat thrust geometries and accompanying thrustrelated fault-propagation and fault-bend folds, 3) out-of-sequence thrusting, 4) rapid changes in structural mode stratigraphically up-section as well as along the strike of the thrust front.

The Lappdalen L1 and L3 thrusts are interpreted as the leading edge thrusts in an eastward propagating thrust system (Fig. 5b), which is linked to a sole thrust in the Gipshuken Formation. Evidence further to the west indicates that a décollement zone exists in shaly units of the Carboniferous strata (Bergh et al. unpublished). We speculate that this lower fault zone may have ramped to a higher stratigraphic level somewhere west of Mediumfjellet and migrated eastward as a flat within the Permian and Triassic sequences. Accordingly, the intense folding of the Permian and Triassic strata in the transition zone is then considered to have been transmitted by simple shear along the Gipshuken décollement zone. Recently described deformation structures in the Gipshuken Formation near Billefjorden (Harland et al. 1988; Ringset 1988; Maher $1988 \mathrm{a}, \mathrm{b})$ suggest that some of this displacement may have been transmitted even further east.
The westward tilted, overall stacked, flat-ramp thrust geometry of the thrust front studied is consistent with a thin-skinned thrust model of emplacement of the strata, confirming models recently presented by Andresen et al. (1988a, b), Bergh et al. (1988a, b), Dallmann et al. (1988) and Nøttvedt et al. (1988). There is a clear genetic relationship between the geometry of most of the hangingwall folds and the footwall geometry. A combined fault-bend and fault-propagation fold model, including foreland (eastward) advancing, piggy-back thrusting, is proposed for the Mediumfjellet and Lappdalen fold-and-thrust zones. Such a model is partly in accordance with Maher's (1988b) interpretation of staircase folds in western Oscar II Land. The documented outof-sequence thrusts, i.e. the Gavltinden and Umefjellet thrusts, are both superimposed on previously formed, predominantly in-sequence structures. One model considers their development as controlled by a previously formed step in the sole-thrust, for example, from the Gipshuken Formation to the Triassic shales.

In view of the above considerations, development of the Mediumfjellet-Lappdalen thrust front is best explained by a two-stage thin-skinned fold-and-thrust model (Fig. 10), as follows: Stage 1: Formation of eastward, in-sequence propagating (piggy-back) ramp-flat thrusts and associated fault-bend and fault-propagation folds in the hangingwall (Fig. 10B, D). The stacking of several thrust sheets in Lappdalen-Mediumfjellet is tentatively related to obstacles in the subsurface. One possibility could be one of the faults controlling the Nordfjorden Block. Another explanation could be an obstacle associated with a dramatic facies change within the St. Jonsfjorden Trough. In our tentative model the sole thrust(s) is inferred to ramp up-section and continue into the foreland as flats within the Gipshuken Formation and/or Triassic strata (Fig. 10C, D). Stage 2: Development of superimposed out-ofsequence thrusts overriding the early generated fold-and-thrusts and resulting in an apparent complex hinterland dipping duplex (Fig. 10E). The roof thrust of this "duplex', represented by the Gavltinden 'out-of-sequence' thrust, was later eroded.

The thrust front studied has several geometrical features in common with thrust fronts as outlined by Morley (1986) and Vann et al. (1986), as shown in Fig. 11. These include elements of faults and folds propagating into the foreland from 


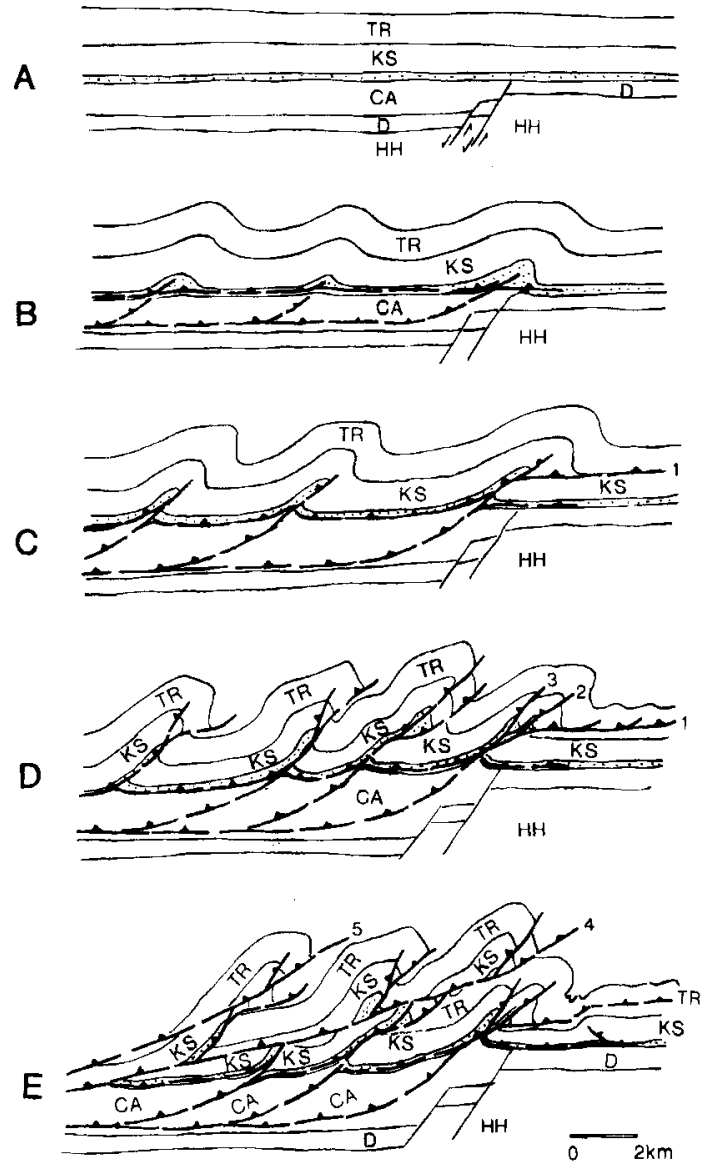

Fig. 10. Highly simplified cartoon for the structural development of the Mediumfjellet-Lappdalen thrust front in east Oscar II Land.

a) Stratigraphical configuration prior to the Tertiary deformation. Carboniferous strata to the west (left) are separated to the east by an inferred Carboniferous normal fault (Pretender Lincament), separating the St. Jonsfjorden trough from the Nordfjorden Block to the west.

b) Incipient Tertiary décollement zones in Permian and Carboniferous strata.

c) Development of fault bend and fault propagation folds above foreland propagating thrusts in the Permian and Carboniferous sequence.

d) Stacking of thrust sheets, tightening of hangingwall folds and backward migration of thrusts (overstep).

e) The last step in the model is development of out-ofsequencc thrusts and formation of a hinterland dipping duplex. Note development of monoclines in the Triassic strata east of the thrust front as a probable consequence of backthrusting above the lower décollement.

major detachments, as well as variable tip line strains above frontal folds (Chapman \& Williams 1984). If the leading edge thrust was developed above a presumed thrust tip (Fig. 12), with

\section{PROPAGATION OF THRUST FRONT INTO THE FORELAND}

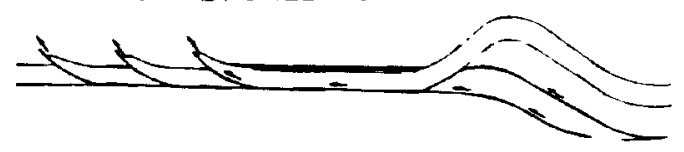

MAJOR BACKTHAUST

AT MOUNTAIN FRONT

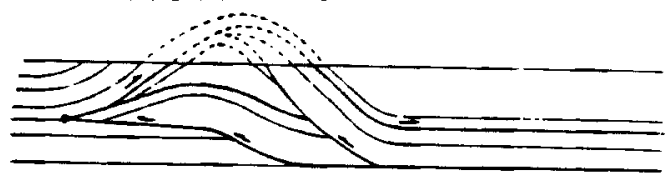

THRUST PROPAGATES

OVER PALAEO LAND SURFACE

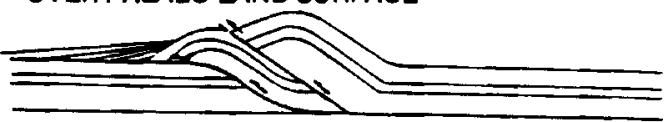

\section{RAPID LOSS OF DISPLACEMENT ALONG THRUST}

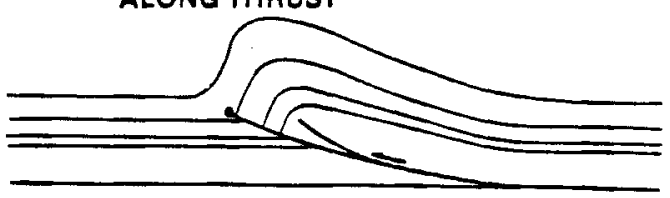

Fig. 11. Summary of characteristic thrust front geometries, after Vann et al. (1986)
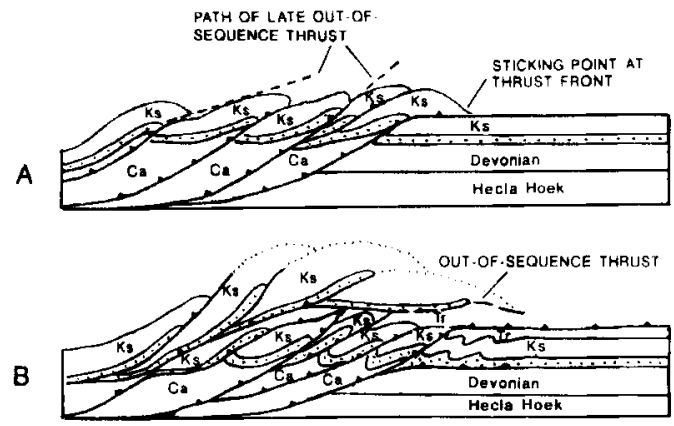

Fig. 12. Development of the Medium-Fjellet-Lappdalen thrust front as a two-stage, tip-stick thrust front. Modified after Morley (1986).

changing position of the thrust tip at different stratigraphic levels, this may explain both 1) the change in fold geometries at the thrust front and 2) the rapid up-section and along strike variation in slip and structural mode noted along the Mediumfjellet-Lappdalen thrust front. 


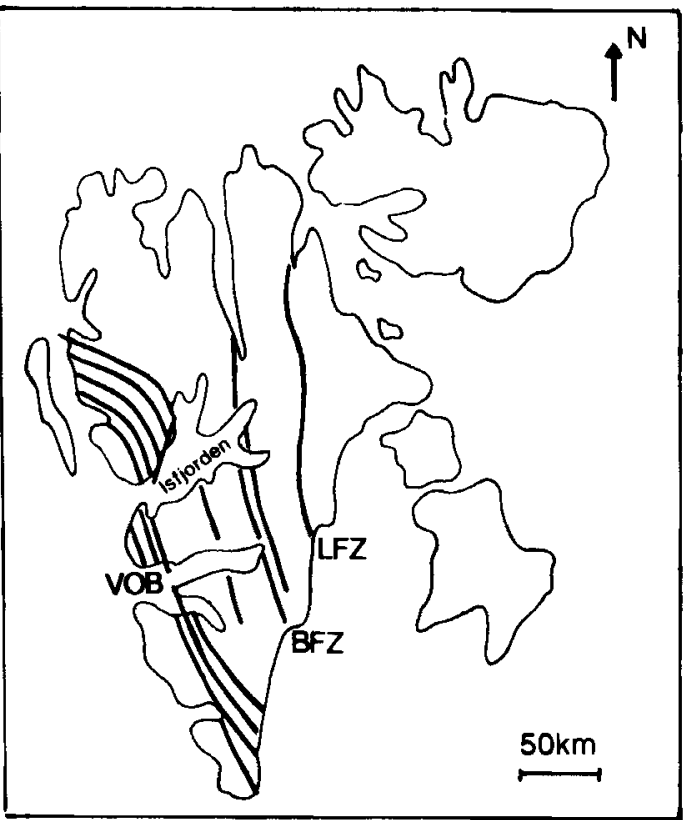

Fig. 13. Simplified map showing the structural trends associated with the Tertiary deformation in Spitsbergen. VOB $=$ Vestspitsbergen Orogenic Belt, LFZ $=$ Lomfjorden Fault Zone, BFZ $=$ Billefjorden Fault Zone.

\section{Regional geological implications}

The Mediumfjellet-Lappdalen thrust front studied exhibits a number of characteristic features that are pertinent for a better understanding of the development of the West-Spitsbergen fold-andthrust belt. One aspect of particular regional interest is to what extent the stratigraphy-lithology of the platform cover sequence in Oscar II Land has controlled the development of décollement planes. Another question is to what extent the position of the studied thrust front is controlled by subsurface older faults.

The literature states that the pre-Tertiary tectonic lineaments in Spitsbergen, e.g. the Pretender, Billefjorden and Lomfjorden Lineaments, controlled the depositional pattern and sedimentary basin development during Carboniferous through Triassic times (Steel \& Worsley 1984; Steel et al. 1985). An excellent example of this is the Carboniferous-Permian sequence of the Billefjorden Trough (Fig. 3), which shows significant facies changes and variations in thickness (Harland et al. 1974). Similarly, the Pretender fault (Harland \&
Horsfield 1974) located north of the area studied may have controlled the development of Carboniferous strata of variable thickness in the St. Jonsfjorden Trough (Fig. 3). These are comprised of interbedded coarse clastic rocks and shaly horizons (Steel \& Worsley 1984), the latter of which may have acted as décollement zones during Tertiary deformation. Furthermore, the structural trend and areas of most intensive Tertiary deformations north of Isfjorden (Fig. 13) closely match the inferred trend of the Carboniferous St. Jonsfjorden Trough and its bordering normal faults (Fig. 3) (Steel \& Worsley 1984). This suggests that the lithofacies configuration and pre-existing faults bordering, for instance, the St. Jonsfjorden Trough as well as other Carboniferous basins in Spitsbergen may have controlled both the nature of the Tertiary deformation and the position and character of the thrust front, including the variable thrusting directions in the cover strata. The dramatic change in structural mode across the MediumfjelletLappdalen thrust front, the apparent change in thrusting directions and the varying width of the foldbelt in Oscar II Land (Lowell 1972; Kellogg 1975) may therefore all be controlled by lithological variations in the Carboniferous strata. Such a model, although speculative at this time, would be consistent with the development of deep-level décollement zones in areas of substantial Carboniferous basin fill material, e.g. in central and west Oscar II Land (Fig. 3). During Tertiary compression, the deep-seated décollement planes ramped to higher stratigraphic levels during eastward propagation.

A similar structural development can be invoked in central Nordenskiöldland, south of Isfjorden. Here, the deformation is relatively mild and is characterized by décollement zones in the Triassic and Jurassic shales (Andresen et al. 1988a), which can be traced below the Central Tertiary Basin to link up with the Billefjorden and Lomfjorden Fault Zones of east Spitsbergen (Andresen et al. 1988a, b; Haremo et al. 1988; Haremo \& Andresen 1988; Nøttvedt et al. 1988). This shallow-level thin-skinned tectonic development differs from the stacked fold-andthrust system, which overlies the décollement planes in Carboniferous-Permian strata north of Isfjorden. The boundary between the two structural provinces north and south of Isfjorden may be the Isfjorden Fault (Harland \& Horsfield 1974). At present we prefer to view the Isfjorden 
Fault as an oblique thrust ramp (Bergh et al. 1988a) which is controlled at depth by the southeastern margin of the St. Jonsfjorden Trough.

Other possible causes of the notable difference in Tertiary deformation style around Isfjorden may be a) the regional southerly plunge of the rocks, with different levels of exposure, b) the thickness of the overburden strata, now eroded, c) the presence of higher thrust sheets, d) probable changes in transport directions along strike (Maher 1988a, b). Future structural research is required to solve these and other questions. In particular, research must be concentrated on areas where Carboniferous and older strata are exposed, in order to identify probable lower detachments.

Similarly, structural studies should be focused on older tectonic lineaments in order to understand how these elements might have controlled the Tertiary deformation structures.

Acknowledgements. - Fieldwork for this project was made possible through financial support from NAVF (Grant 440.89/ 003), Oljedirektoratet, Norsk Polarinstitutt and Statoil. We also received important logistical support from SNSK, Norsk Hydro and Norsk Polarinstitutt. Amy Dale helped us with the English grammar and Hilkka Falkseth drafted the final version of all the maps and geological cross-sections.

\section{References}

Andresen, A., Bergh, S. G., Hansen, H., Kløvjan, O., Kristensen, S. E., Livbjerg, F., Lund, T., Mair, B. F., Midbøe, P. \& Nøttvedt, A. 1988a: Geometry and structural development of the Billefjorden and Lomfjorden Fault Zones in the Isfjorden-Sabine Land Area, Spitsbergen. Abstract. 18. Nordiske Geologiske Vintermøde, København, 33-34.

Andresen, A., Harcmo, P. \& Bergh, S. G. 1988b: The southern termination of the Lomfjorden Fault Zone; evidence for Tertiary compression on east Spitsbergen. Norsk Polarinstitutt Rapport 46, 75-78.

Bergh, S. G., Andresen, A., Berguik, A. \& Hansen, A.-I. 1988a: Tertiary thin-skinned compressional deformation on Oscar II Land, central West-Spitsbergen. Norsk Polarinstitutt Rapport 46, 51-54.

Bergh, S. G., Andresen, A., Hansen, S. \& Wennberg, O. P. 1988b: Geometri og kinematikk i skyvefrontenheter ved Lappdalen og Mediumfjellet, Isfjorden, Vest-Spitsbergen. Abstract. Geolognytt 22, 17.

Birkenmajer, K. 1972: Tertiary history and continental drift. Acta Geologica Polonica 22, 193-218.

Boyer, S. E. \& Elliott, D. 1982: Thrust systems. Am. Ass. Petrol. Geol. Bull. 66, 1196-1230.

Butler, R. W. H. 1982: The terminology of structures in thrust belts. Journ. Struct. Geol. 4, 229-245.

Challinor, A. 1967: The structure of Brøggerhalvøya, VestSpitsbergen. Geol. Mag. 104, 322-336.
Chapman, T. J. \& Williams, G. D. 1984: Displacement distance methods in the analysis of fold-thrust structures and linked fault systems. J. Geol. Soc. Lond. 141, 121-128.

Dallmann, W. K., Ohta, Y. \& Andresen, A. 1988: Tertiary tectonics of Svalbard. Extended abstracts from Symposium held in Oslo 26 and 27 April 1988. Norsk Polarinstitut Rapport 46. $110 \mathrm{pp}$

Eldholm, O., Faleide, J. I. \& Myhre, A. 1987: Continentocean transition at the western Barents Sea/Svalbard continental margin. Geology 15, 1118-1122.

Elliott, D. \& Johnson, M. R. W. 1980: Structural evolution in the northern part of the Moine thrust belt, N.W. Scotland. Trans. R. Soc. Edinb. Earth Sci. 71, 69-96.

Haremo, P. \& Andresen, A. 1988: Tertiary movements along the Billefjorden Fault Zone and its relation to the Vestspitsbergen orogenic belt. Norsk Polarinstitutt Rapport 42, 71-74.

Haremo, P., Andresen, A., Strand, K., Dypvik, H., Nagy, J., Elverhøi, A., Eikeland, T. A. \& Johansen, H. 1988: Strukturell utvikling av de mesozoiske og tertiære bergartene i området Adventdalen/Sassendalen-Kjellströmdalen, sentrale Spitsbergen, Svalbard. Abstract. 18. Nordiske Geologiske Vintermøde, Københaun, 155.

Harland, W. B. 1969: Contribution of Spitsbergen to understanding of tectonic evolution of North Atlantic region. Pp. 817-851 in Kay, M. (ed.): North Atlantic - geology and continental drift. Mem. Am. Ass. Petrol. Geol. I2.

Harland, W. B. \& Horsfield, W. T. 1974: West Spitsbergen Orogen. Pp. 747-755 in Spencer, A. M. (ed.): Data for orogenic studies. Geol. Soc. Lond. Spec. Publ. 4.

Harland, W. B., Cutbill, J. L., Friend, P. F., Gobbett, D. J., Holliday, D. W., Maton, P. I., Parker, J. R. \& Wallis, R. H. 1974: The Billefjorden Fault Zone, Spitsbergen - the long history of a major tectonic lineament. Norsk Polarinstitut Skrifter 161. 72 pp.

Harland, W. B., Mann, A. \& Townsend, C. 1988: Deformation of anhydrite-gypsum rocks in central Spitsbergen. Geol. Mag. $125,103-116$.

Holtedahl, O. 1913: Zur Kenntis der Karbonablagerungen des westlichen Spitzbergen. II. Allgemeine stratigraphische und tektonische beobachtungen. Jacob Dybwad, Kristiana (Oslo). $91 \mathrm{pp}$.

Jamison, W. R. 1987: Geometric analysis of fold development in overthrust terranes. Journ. Struct. Geol. 9, 207-219.

Jones, P. B. 1984: Sequence of formation of back-limb thrust and imbrications: Implications for devclopment of IdahoWyoming Thrust Belt. Am. Ass. Petr. Geol. Bull. 68, 816818.

Kellogg, H. E. 1975: Tertiary stratigraphy and tectonism in Svalbard and continental drift. Amer. Ass. Petrol. Geol. Bull. 59, 465-485.

Lowell, J. D. 1972: Spitsbergen Tertiary orogenic belt and the Spitsbergen fracture zone. Geol. Soc. Am. Bull. 83, 30913102.

Maher, H. D. 1988a: Photointerpretation of Tertiary structures in interior Oscar II Land, Spitsbergen. Norsk Polarinstitut Rapport 42, 55-58.

Maher, H. D. 1988b: Photointerpretation of Tertiary structures in platform cover strata of interior Oscar II Land, Spitsbergen. Polar Research 6, 155-172.

Mitra, S. 1988: Three dimensional geometry and kinematic evolution of the Pine Mountain thrust system, southern Appalachians. Geol. Soc. Am. Bull. 100, 72-95.

Morley, C. K. 1986: A classification of thrust fronts, Am. Ass. Petrol. Geol, Bull. 70, 12-25. 
Morley, C. K. 1988: Out-of-sequence thrusts. Tectonics 7, 539561.

Mybre, A. M., Eldholm, O.\& Sundvor, E. 1982: The margin between Senja and Spitsbergen fracture zones: implications from plate tectonics. Tectonophysics 89, 33-50.

Mørk, A., Knarud, R. \& Worsley, D. 1982: Depositional and diagenetic environments of the Triassic and Lower Jurassic succession of Svalbard. Pp. 371-398 in Embry, M. \& Balkwill, H. R. (eds.): Arctic Geology and Geophysics. Can. Soc. Petrol. Geol. Mem. 8.

Nøttvedt, A., Livbjerg, F. \& Midbøe, P. S. 1988: Tertiary deformation of Svalbard - various models and recent advances. Norsk Polarinstitutt Rapport 46, 79-84.

Ohta, Y. 1988: Basement of W-Spitsbergen; an outline. Norsk Polarinstitutt Rapport 46, 9-12.

Orvin, A. K. 1934: Geology of the Kings Bay region, Spitsbergen. Skrifter om Sualbard og Ishavet $78.98 \mathrm{pp}$.

Orvin, A. K. 1940: Outline of the geological history of Spitsbergen Skrifter om Svalbard og Ishavet 78, 1-57.

Ramsay, J. G. \& Huber, M. I. 1987: The techniques of modern structural geology 2. Folds and fractures. Academic Press. 700 pp.

Ringset, N. 1988: The fold-and-thrust system of Midter- hukfjellet, Bellsund. Norsk Polarinstitutt Rapport 42, 39 42.

Schmidt, C. J. \& O'Neill, M. J. 1982: Structural evolution of the southwest Montana transverse zone: Denver, Colorado. Rocky Mountain Ass. of Geol. Symp. I, 193-218.

Steel, R. J. \& Worsley, D. 1984: Svalbard's post-Caledonian strata - an atlas of sedimentational patterns and paleogeographic evolution. Pp. 109-135 in Petroleum Geology of the North European Margin. Norwegian Petroleum Society.

Steel, R. J., Gjelberg, J., Helland-Hansen, W., Kleinspehn, K., Nøttvedt, A. \& Larsen, M. R. 1985: The Tertiary strikeslip basins and orogenic belt of Spitsbergen. Pp. 339-359 in Biddle, K. T. \& Cristie-Blick, N. (eds.): Strike-slip deformation, basin formation, and sedimentation. Soc. Econ. Paleont. Miner. Spec. Publ. 37.

Suppe, J. 1983: Geometry and kinematics of fault-bend folding. Am. Journal of Science 283, 684-727.

Vann, I. R., Graham, R. H. \& Hayward, A. B. 1986: The structure of mountain fronts. Journ. Struct. Geol. 8, 215227.

Williams, G. \& Chapman, T. 1983: Strain developed in the hanging-walls of thrusts due to their slip/propagation rate: a dislocation model. Journ. Struct. Geol. 5, 563-571. 